\title{
Electronic Educational Resources As Means of Formation of the Foreign-Language Professionally Focused Competence of Future Philologists
}

\author{
Gulyusa R. Zamaletdinova, Natalia V. Konopleva, Natalia V. Gorbunova
}

\begin{abstract}
In the current conditions of society development, the most in demand are the educational level of employees, their professionalism, learning ability, creativity, and high intelligence. This has led to a trend of increasing requirements for graduates of higher education institutions. Taking into account that recent years have been marked by international integration, the quality of training of future philologists should ensure correspondence of all training aspects to the requirements of the applicable standard of education, an adequate level of foreign language command to the extent necessary for the free general and professional communication, the ability to freely navigate in the information field of foreign sources.
\end{abstract}

This study reveals new perspectives and opportunities for the use of electronic educational resources (EER) in education, which allow the use of such effective tools as interactive means, multimedia, communication and productivity.

In the process of training, opportunities arise to take advantage of information technologies, including electronic educational resources: electronic textbooks, multimedia, sites, portals, UDACITY and Udemy platforms; Web-2.0 services, new smart technologies, wiki technologies, podcasts, and webinars.

Keywords: electronic educational resources, foreign language professional competence, future philologists.

\section{INTRODUCTION}

One of the trends in the modern education system has been the widespread use of massive open online courses. The content and specific of the process modelling (designing) of the teachers' activity in the field of supplementary education in accordance with the professional standards and the Conception of children's supplementary education development is absorbed through personal and meaning acquisition of the normative legal field of modern supplementary education [1].

The research problem is actualized by the need to improve the quality of higher education, search for effective methods and technologies, process a significant amount of information and operate with it, and use electronic educational resources. As a rule, foreign words first of all get into mass media and only then, being widely used in advertising, enter dictionaries [2]. The wide possibilities of electronic educational resources motivate students to operate modern educational materials, and also such effective tools as interactive, multimedia, communication and productivity. Students should select texts based on the language of their future specialty, make assignments for the consolidation of the passed terminology [3].

\section{METHODS}

In compliance with the purpose and the objectives stated above, the following research methods were employed at various stages of the research:

- Empirical: survey, observation, testing, analysis of the results of the educational and scientific activities of future philologists; pedagogical experiment (stating, formative and control stages);

- Methods of mathematical statistics: for quantitative and qualitative analysis of the results of the pedagogical experiment.

The pedagogical experiment was being conducted on the base of Humanities and Education Science Academy (branch) in Yalta of V.I. Vernadsky Crimean Federal University. Effective communication, in its turn, is impossible without certain language skills [4].

\section{RESULTS}

The study is aimed at the formation of professionally oriented foreign language competence of future philologists by means of electronic educational resources. In order to identify the initial level of formation of a professionally oriented foreign language competence of future philologists, criteria (motivational, cognitive, operational, and reflective) are identified. The selected criteria were specified in indicators, the formation of which was checked using specially selected diagnostic tools.

We used testing and conversation with a subsequent survey as part of a cognitive criterion for checking such indicators as: the high level of English proficiency; the ability to master and operate professionally oriented material in a foreign language. The results of the ascertaining stage are presented in table 1 . 
Table 1: Levels of formation of professionally oriented foreign language competence of future philologists at the ascertaining stage

\begin{tabular}{|l|c|c|}
\hline Level & Experimental group & Control group \\
\hline Creative & $3.28 \%$ & $3.24 \%$ \\
\hline Productive & $9.56 \%$ & $9.75 \%$ \\
\hline Medium & $45.11 \%$ & $44.01 \%$ \\
\hline Low & $42.06 \%$ & $42.30 \%$ \\
\hline
\end{tabular}

In the experimental group, the creative level of formation of professionally oriented foreign language competence was mastered by $3.28 \%$ of future philologists, in the control group $-3.24 \%$; $9.56 \%$ of the surveyed persons in the experimental group and $9.75 \%$ of the respondents in the control group showed a productive level; $45.11 \%$ of the surveyed persons in the experimental group and $44.01 \%$ of students in the control group were at a medium level; $42.06 \%$ of the surveyed subjects in the experimental group and $42.30 \%$ of the future philologists in the control group were at a low level of formation of professionally oriented foreign language competence.

The analysis of the obtained data has recorded a low level of formation of professionally oriented foreign language competence for the students, which led to the need for focused work.

The formation of professionally oriented foreign language competence of future philologists was carried out over four stages: motivational, communicative, professional and reflective.

The purpose of the motivational phase was the development of motivation for the formation of professionally oriented foreign language competence. During such forms of work as conducting practical classes in a computer class (Internet services Quizlet, Mindmap, podcasts), and round tables using discussions and quests, a pedagogical condition is being realized - motivation for foreign language communication and mastering innovative teaching technologies. The result of the work at the motivational stage is the motivation of students to learn a foreign language using electronic educational resources.

During the communicative stage, professional communicative competence was formed in order to increase the effectiveness in professional activity. The pedagogical condition was the organization of focused work on the formation of professionally oriented foreign language competence; it was realized during practical classes with electronic materials, interactive exercises, hyperlinks, lexical, pretext, post-text, and communicative tasks. The expected result of the second stage was the mastery of a foreign language for oral and written communication at a creative and productive level.

The purpose of the professional stage was the development of professionally significant personality traits that ensure the formation of a professionally oriented foreign language competence with the help of a pedagogical condition - the dominance of active and interactive methods. The professional phase work content provided the development of presentations, the creation of electronic educational resources, participation in conferences, as a result of which students used a foreign language in their professional activities at a productive level.

The work at the reflexive stage was focused on self-assessment by students of their achievements and the results of the formation of professionally oriented foreign language competence. The implementation of the pedagogical condition is the provision of systematic control over the level of formation of professionally oriented foreign language competence. The forms of work at this stage were the creation and analysis of educational and creative projects, webinars; testing to assess the ability to plan their educational activities. The implemented content of the work allowed the following result to ensure: fluency in a foreign language in professional activities.

The purpose of the control stage was to identify the effectiveness of the work done to form a professional-oriented foreign language competence of future philologists using electronic educational resources. For this purpose, future philologists were asked to perform diagnostic methods similar to the tasks of a stating experiment: questioning, interviews, tests, analysis of students' independent and creative work, speeches at scientific student conferences and publications in collections.

A comparative analysis of the research results for the experimental and control groups is presented in table 2 .

Table 2: Comparative formation levels of professionally oriented foreign language competence of future philologists

\begin{tabular}{|l|c|c|c|c|}
\hline \multirow{2}{*}{ Levels } & \multicolumn{2}{|c|}{ Experimental group } & \multicolumn{2}{c|}{ Control group } \\
\cline { 2 - 5 } & $\begin{array}{c}\text { Ascertaining } \\
\text { experiment }\end{array}$ & Control experiment & $\begin{array}{c}\text { Ascertaining } \\
\text { experiment }\end{array}$ & Control experiment \\
\hline Creative & $3.28 \%$ & $16.74 \%$ & $3.24 \%$ & $5.28 \%$ \\
\hline Productive & $9.56 \%$ & $28.50 \%$ & $9.75 \%$ & $12.13 \%$ \\
\hline Medium & $45.11 \%$ & $43.12 \%$ & $44.72 \%$ & $47.10 \%$ \\
\hline Low & $42.06 \%$ & $11.64 \%$ & $42.30 \%$ & $35.49 \%$ \\
\hline
\end{tabular}

In the experimental group, the creative level increased from $3.28 \%$ in the period of observation to $16.74 \%$ during the control examination. The productive level increased from 9.56\% during the ascertaining examination to $28.5 \%$ at the control stage. The number of respondents with a medium level formation of a professionally oriented foreign language competency slightly decreased: from $45.11 \%$ at the ascertaining stage to $43.12 \%$ at the control stage. The number of students who have demonstrated a low level of formation of a professionally oriented foreign language competency has decreased: from $42.06 \%$ at 
the ascertaining stage to $11.64 \%$ at the control.

In the control group, minor positive changes occurred. The number of respondents who have reached the creative level increased from $3.24 \%$ during the ascertaining examination to $5.28 \%$ during the control diagnostics. Increase in the number of students that have been identified as reached productive (with $9.75 \%$ for the ascertaining step to $12.13 \%$ - in the control) and medium levels of formation of oriented foreign language professional competence (with $44.72 \%$ for the ascertaining step to $47.1 \%$ - on the control), has been obtained. The number of students with a low level of formation of a professionally oriented foreign language competency has decreased: from $42.3 \%$ when ascertaining to $35.49 \%$ during the control examination.

The growing popularity of massive open online courses has caused widespread discussion, confirming the fact that they have a noticeable effect on current trends in education. Observations of the UNESCO Institute for Information Technologies in Education predicted that by 2019, almost half of the classroom activities will be conducted online [3]. Several leading platforms of massive open online courses have gained great popularity: the non-profit edX project; commercial company Coursera, with the participation of Stanford and Princeton universities, universities of Michigan and Pennsylvania; UDACITY, Udemy and others. A modern educational platform "Open Education" created by leading universities of the country, and also Intuit and Universarium interuniversity e-Learning platforms have appeared in Russia. Since 2002, a unique Internet resource in the field of education and science, i.e. the Federal portal "Russian Education" has been operating. The Information system "Single window of access to educational resources" (IS "Single window") is functioning successfully.

\section{DISCUSSION}

When training future philologists, learning management systems (LMS) like Black board or Moodle with the help of e-mail and software simulators have great potential. For teaching foreign languages, the materials of the Internet are important, in particular, Web 2.0 services that provide a comprehensive approach to the organization, implementation and support of Web resources [6, 7, 8, 9, 10].

Considerable attention in teaching languages is given to audiovisual clarity. However, at the present stage, schoolchildren are often not able to empathize, they are inclined to pragmatic reading, to receive information, and only during the analysis of a fictional work can they understand the depth of the text's intention and experience certain emotions [11]. Scientists described the principles of selecting audio / video materials, and also tasks and methods of working with them in accordance with communicative and professional competence. The basic requirements to video materials according to which the learning process will be successful are listed; the advantages of using video films and attracting audiovisual visibility are highlighted [12].

Researchers are interested in questions regarding the content and structure of training programs for highly qualified teachers-philologists. The document of the European Commission on the European profile of the foreign language teachers training (2004) considers 40 subjects as important in the training of teachers of foreign languages. The main goal of training is to determine the structure, knowledge, strategies and values at which European academic programs for primary education of language teachers pay special attention. The best practices were identified, ways of improving existing academic programs were recommended to expand the cooperation of participants in the policy of teaching language teachers [13-19].

Proponents of blended learning as one of the innovations in language education emphasize that it is such learning that combines traditional teaching methods with modern teaching technologies. Researchers believe that it is impossible to ignore personal differences, the importance of self-motivation and the advantages of computers as a material, especially for the young generation that has grown today in the world of computers and the Internet [14-17-18].

Until recently, computer language learning has been a topic mainly related to those with particular interest in this area. The effectiveness of information and computer technologies cannot depend on the medium itself, but depends only on how it is used [15-20].

\section{SUMMARY}

In connection with advances in information technology, new opportunities are opening up for the development and improvement of the educational process. Information technologies today have significant didactic potential, which allows motivating students to master professional activities. The willingness of teenagers to implement the idea through modern computer technologies and the ability to independently select and use art materials, techniques and their combinations according to the subject and the design task have noticeably increased [16].

A comparative analysis of the experimental work results has showed a significant increase in the level of formation of professionally oriented foreign language competence of future philologists in the experimental group, where significant positive changes in the distribution of levels were revealed.

\section{CONCLUSION}

Despite its completeness and consistency, the study does not exhaust all aspects of the problem. We see our research prospects in the further improvement of teaching aids and electronic educational resources for the formation of professionally oriented foreign language competence, the development of an electronic implementation of the educational and methodological support for a foreign language course using the LMS Moodle learning management system.

\section{ACKNOWLEDGEMENTS}

The work is performed according to the Russian Government Program of Competitive Growth of Kazan Federal University.

\section{REFERENCES}

1. Galiya M. Gatiyatullina, Aleksander S. Kiselnikov, Fanuza Kh Tarasova, Dilyana D. Sungatullina, Elzara V. Gafiyatova Text Complexity Modification By Means Of It-Technologies//Modern Journal of Language Teaching Methods. Vol. 8, Issue 10, October 2018- pp. 396-401. (WoS)

2. Liliya R. Mukharlyamova, Alsu Kh. Ashrapova, Svetlana Alendeeva Borrowed words in 
language teaching (on the economic term system of the Russian language in the XXI century) // Journal of Language and Literature, ISSN: 2078-0303, Vol. 7. No. 2. May, 2016 P.163-168.

3. Erofeeva Anna A., Yusupova Zulfiya F., Actual problems of teaching russian language as the language of the specialty of foreign students // Revista Publicando. - 2018. - Vol.5, Is. 16. - P. 324-331.

4. Kuzmina E.K, Nazarova G.I, Nizamieva L.R, Innovative technologies of teaching business French//International Journal of Engineering and Technology(UAE). - 2018. - Vol.7, Is.4. - P.85-87.

5. Badarch, D., Tokareva N.G., Tsvetkova M.S. Mass open online course: reconstruction of higher education [Electronic resource] / D. Badarch // Higher education in Russia. - 2014. - No. 10. - URL: https://cyberleninka.ru/article/n/mook-rekonstruktsiya-vysshego-obra zovaniya (accessed: 01.03.2018)

6. Kolesova, T.V. Organization of the environment for independent study of English by means of information and computer technologies in a university / T.V. Kolesova // Education and self-development. - Kazan: Centre for Innovative Technologies, 2013. - No. 2 (36). - S. 18-24.

7. Krivitsky, B.Kh. About systematization of educational computer means / B.Kh. Krivitsky // Educational Technology \& Society. - 2000. - Volume 3 (3) - 548-556 pp.

8. Canale, M. On some dimensions of language skill / M. Canale, J.V. Oller (editor) // Proceedings of the study of language testing. - Rowley, Mass.: Ed.Newbury House, 1983. - Pp. 332-342.

9. Dragunova, A.A. Educational Internet resources as a means of forming professional foreign language communicative competence of students / A.A. Dragunova // Yaroslavl Pedagogical Bulletin. - 2011. - No. 1. Pp. 163-167.

10. Palkova, A.V. Application of Web 2.0 services in teaching foreign languages / A.V. Palkova // Teaching foreign languages in multimedia space: a collection of scientific articles - Tver: Tver State University, 2012. - Pp. 69-85.

11. Kayumova G.F, Makarova V.F, Galiullin R.R, Moral education of high school students in national (TurkiC) schools through literature // International Journal of Mechanical Engineering and Technology. 2018. - Vol. 9, Is. 10. - P.1467-1475.

12. Aleksandra E. Massalova, Julia V. Rzhanikova, Elena V. Dziuba Formation of Motivation for Studying Russian as a Foreign Language in Cadets of a Military Engineering University Through Audiovisual Visibility // Astra Salvensis - review of history and culture, year VI, Supplement no. 1, 2018.

13. Marianthi Karatsiori, Kris Gritter. European profile for language teacher education: Meeting the challenge for sharing common competences, knowledge, strategies and values // Journal Cogent Education. Volume 3, 2016. - Issue 1. - P. 1-29.

14. Deniz Yalçınkaya. Why is Blended Learning for Vocationally Oriented Language Teaching? // Procedia - Social and Behavioral Sciences 174:1061-1068. February 2015 with 52 Reads. DOI: 10.1016/j.sbspro.2015.01.795.

15. Mark Warschauer. Computer Assisted Language Learning: an Introduction (1996) «Computer Assisted Language Learning: an Introduction». In Fotos S. (ed.) Multimedia language teaching, Tokyo: Logos International: 3-20.

16. Mishina Nadezda, Javgildina Zilia, Mishina Anastasia, Design Practice as a Method of Professional Orientation of Teenagers in the System of Supplementary Education // Tarih Kultur Ve Sanat Arastirmalari Dergisi-Journal of History Culture and Art Research. 2018. - Vol.7, Is.4. - P. 132-137.

17. Luo, C., Li, M., Peng, P., \& Fan, S. How Does Internet Finance Influence the Interest Rate? Evidence from Chinese Financial Markets. Dutch Journal of Finance and Management, 2(1), (2018). 01.

18. Torquato, M., Araujo, J., Umesh, I. M., \& Maciel, P. SWARE: A Methodology for Software Aging and Rejuvenation Experiments. Journal of Information Systems Engineering \& Management, 3(2), (2018). 15.

19. Marbán, J. M., \& Mulenga, E. M. Pre-service Primary Teachers' Teaching Styles and Attitudes towards the Use of Technology in Mathematics Classrooms. International Electronic Journal of Mathematics Education, 14(2), (2019). 253-263. https://doi.org/10.29333/iejme/5649

20. Feizuldayeva, S., Ybyraimzhanov, K., Mailybaeva, G., Ishanov, P., Beisenbaeva, A., \& Feizuldayeva, S. Vocational training of future elementary school teacher by means of realization of inter-subject continuity. Opción, 34(85-2), (2018). 479-516 